\title{
Pengaruh Senam Bugar Muhammadiyah Terhadap Kebugaran Jasmani Siswa SMP
}

\section{The Effect of Muhammadiyah Gymnastics on Physical Fitness of Junior High School Students}

\author{
Dani Wardani ${ }^{1}$, Alwi Nurudin ${ }^{2}$ \\ 1,2 Fakultas Keguruan dan IImu Pendidikan, Universitas Muhammadiyah Sukabumi \\ email: daniwardani530@gmail.com¹ , ahmadalwi@ummi.ac.id² \\ do: https://doi.org/10.20884/1.paju.2020.2.1.3330
}

\begin{abstract}
Abstrak
Kebugaran jasmani menjadi fakrot penting dalam pencapaian prestasi belajar siswa. Salah satu metode yang dapat digunakan dalam meningkatkan kebugaran jasmani yaitu senam kebuigaran. Penelitian ini bertujuan untuk meningkatkan kebugaran jasmani siswa Kelas VIII. H SMP Negeri 1 Kadudampit Kabupaten Sukabumi. Metode penelitian yang digunakan yaitu pre-experimental dan tehnik purposive sampling. Sampel pada penelitian ini yaitu ssiwa kelas VIII dengan jumlah 4 orang. Hasil dari penelitian setelah siswa melakukan latihan senam bugar muhammadiyah diperoleh hasil bahwa siswa dengan kategori kurang sekali 50\%, kategori kurang 25\% dan kategori sedang $25 \%$. Berdasarkan hasil tersebut menunjukan bahwa senam bugar muhammadiyah tidak berpengaruh terhadap peningkatan kebugaran jasmani siswa kelas VIII SMP Negeri 1 Kadudampit Kabupaten Sukabumi, hal ini dikarenakan pada saat pemberian perlakuan senam bugar muhammadiyah sampel tidak menguasai gerakan dengan baik sehingga mempengaruhi terhadap hasil kebugaran dari setiap individu. Saran dari peneltian ini yaitu senam bugar Muhamadiyah perlu dikaji lebih jauh dengan menggunakan jumlah sampel yang lebih banyak dan dengan metode latihan yang lebih terprogra, sehingga dapat diketahui pengaruh yang lebih nyata
\end{abstract}

Kata Kunci : Senam Bugar Muhammadiyah, Kebugaran, Siswa SMP

\begin{abstract}
Physical fitness is an important factor in achieving student achievement. One of the methods that can be used to improve physical fitness is fitness exercise. This study aims to improve the physical fitness of Grade VIII students H SMP Negeri 1 Kadudampit, Sukabumi Regency. The research method used was preexperimental and purposive sampling technique. The sample in this study was 4 students of class VIII. The results of the research after the students did the Muhammadiyah fitness exercises showed that the students were under $50 \%$ less category, 25\% less category and 25\% moderate category. Based on these results, it shows that Muhammadiyah fitness has no effect on improving the physical fitness of the VIII grade students of SMP Negeri 1 Kadudampit, Sukabumi Regency, this is because at the time of giving the Muhammadiyah
\end{abstract}

Alamat Koresponden : Fakultas Keguruan dan IImu Pendidikan, Universitas Muhammadiyah Sukabumi

Email : daniwardani530@gmail.com

\section{(c) (7)}

Jurnal Physical Activity Journal (PAJU) This work is licensed under a Creative Commons Attribution $\underline{4.0 \text { International License. }}$ 
fitness exercise treatment the sample does not master the movement well so that it affects the fitness results of each individual. The suggestion from this research is that the Muhamadiyah fitness gymnastics needs to be studied further by using a larger number of samples and with a more programmed training method, so that a more real effect can be seen.

Keywords : Muhammadiyah Fitness Gymnastics, Fitness, Junior High Students

\section{PENDAHULUAN}

Kebugaran jasmani adalah hal yang harus dimiliki oleh setiap manusia. Kebugaran jasmani yang baik akan berdampak positif bagi manusia dalam melakukan aktivitas seharihari tanpa merasakan kelelahan berlebih bahkan tidak menimbulkan masalah kesehatan. Kebugaran jasmani adalah derajat sehat dinamis seseorang yang menjadi kemampuan jasmani dasar untuk melaksanakan tugas yang harus dilaksanakan (Satriya et al., 2013; Juliasti, Kuswari, \& Jus'at, 2020). Kebugaran jasmani adalah kualitas seseorang untuk melakukan aktivitas sesuai dengan pekerjaanya secara optimal tanpa menimbulkan masalah kesehatan dan kelelahan yang berlebihan (Edo, 2017; Kusnandar, Purnamasari, Nurcahyo, \& Darjito, 2019; Suhartoyo et al., 2019). Berdasarkan para ahli diatas kebugaran jasmani adalah derajat sehat dinamis seseorang untuk melaksanakan aktivitasnya secara optimal tanpa menimbulkan masalah kesehatan dan kelelahan yang berlebih.

Olahraga adalah kegiatan fisik yang penting untuk diperhatikan oleh manusia. Bila dilakukan secara teratur ini merupakan salah satu bagian dari gaya hidup sehat yang mana dapat mengembangkan keterampilan dalam upaya mengembangkan diri dan pemeliharaan kebugaran jasmani, rohani, sosial, serta terhindar dari berbagai penyakit. Bentuk olahraga yang mampu mengolahragakan masyarakat adalah olaharaga pendidikan, olahraga prestasi dan olahraga rekreasi. Hal ini dijelaskan dalam UndangUndang Republik Indonesia No 3 pasal 1 ayat 12 tahun 2005 tentang Sistem Keolahragaan Nasional bahwa: Olahraga rekreasi adalah olahraga yang dilakukan oleh masyarakat dengan kegemaran dan kemampuan yang tumbuh dan berkembang sesuai dengan kondisi dan nilai budaya masyarakat setempat untuk kesehatan, kebugaran, dan kesenangan. Dari kutipan diatas jelas bahwa masyarakat dapat berolahraga melalui olahraga rekreasi yang dilakukan dengan kegemaran dan kemampuan. 
Dani Wardani \& Alwi Nurudin | Pengaruh Senam Bugar Muhammadiyah Terhadap Kebugaran Jasmani Siswa SMP

Banyak jenis olahraga rekreasi yang dapat memelihara kebugaran jasmani salah satunya yaitu senam bugar muhammadiyah. Senam adalah salah satu olahraga yang dapat diikuti oleh semua kalangan baik dilingkungan sekolah maupun masyarakat karena senam bersifat murah meriah, menyenangkan, dan dapat dilakukan dengan bersamasama. Senam umum adalah bagian dari senam yang mana pelaksanaanya menggunakan musik. Yang termasuk pada senam umum adalah senam aerobik, skj (senam baku), pocopoco, maumere dan zumba (Rubiana, 2020).

Senam bugar muhammadiyah adalah salah satu jenis senam baru yang dijadikan sebagai senam umum/baku yang gerakannya dapat diikuti secara bersama-sama sehingga dapat meningkatkan kebugaran jasmani. Wening (2018) menjelaskan bahwa senam bugar muhammadiyah adalah salah satu senam yang dapat digunakan sebagai salah satu Latihan jasmani untuk meningkatkan derajat kebugaran tubuh. Hal ini peneliti lakukan dengan menggunakan senam bugar muhammadiyah sebagi perlakuan penelitian pada usia 13-15 tahun siswa kelas VIII. H SMP Negeri 1 kadudampit Kabupaten Sukabumi.

Berdasarkan pengamatan peneliti dengan melihat fenomena diera zaman milineal ini yang melek akan teknologi yang bertampak pada kurangnya aktivitas olahraga sering. Hal ini membuat generasi muda terutama pada siswa di sekolah tidak sadar akan banyaknya aktivitas fisik yang di gantikan oleh teknologi, sehingga menjadikan salah satu faktor malas melakukan aktifitas gerak fisik, siswa kelas VIII. H SMP Negeri 1 kadudampit Kabupaten Sukabumi mayoritas siswa berangkat kesekolah dengan menggunakan kendaraan pribadi maupun umum meskipun jarak tempat tinggal dekat dengan sekolah dan tidak mengikuti ekstrakulikuler olahraga disekolah. Tujuan dari peneltiian ini yaitu untuk mengetahui pengaruh latihan senam bugar muhamadiyah terhadap peningkatan kebugaran jasmani siswa.

\section{METODE}

Metode penelitian adalah cara untuk mengetahui hasil dari penelitian yang diambil dari jumlah sempel. Sugiyono (2012) menjelaskan ada dua jenis penelitian experiment yaitu true experimental (eksperiment sungguh-sungguh) dan pre-experimental designs 
(non designs) design ini belum exsperiment sungguh-sungguh, karena masih terdapat variabel luar yang mempengaruhi variabel independen.

Desain penelitian yang digunakan yaitu one group prestest postest design (belum sunggu-sungguh) dan eksperimen yang dilakukan hanya pada satu kelompok saja tanpa kelompok pembanding. Desain peneilitan dalam bentuk gamabar sebagai berikut:

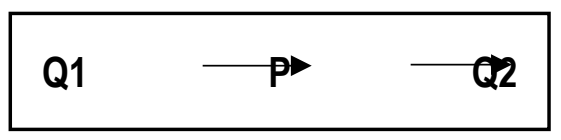

\section{Gambar 1 Desain Penelitian One Grup Pretest Design}

Penelitian ini dilakukan di SMP Negeri 1 Kadudampit Kabupaten Sukabumi tahun ajaran 2020/2021, dimulai pada jam 07.00 sampai jam 08:00, penelitian ini dilaksanakan pada tanggal 3 Agustus 2020- 28 Agustus dengan 12 kali pertemuan dan 3 kali dalam satu pekan. Populasi pada penelitian ini yaitu siswa kelas VIII. H SMP Negeri 1 Kadudampit Kabupaten Sukabumi tahun ajaran 2020/2021 dengan jumlah sampel 4 orang yang berusia 13-15 tahun sesuai norma instrument penelitian Tes Kbugaran Jasmai Indonesia.

Instrumen penelitian menggunakan Tes Kebugaran Jasmani Indonesia mengetahui hasil awal dan akhir dalam hasil satuan waktu dan diakumulasikan sesuai norma. Menurut Rahmat (2016) Tes Kebugaran Jasmani Indonesia (TKJI) adalah suatu tolak ukur untuk mengukur tingkat kebugaran jasmani yang berbentuk rangkaian butir-butir tes yang menjadi salah satu tolak ukur dalam mengetahui tingkat kebugaran jasmani anak yang digolongkan sesuai dengan umur siswa tersebut yang terbagi 4 golongan yang dibedakan sesuai golongan umur, yaitu: 6-9 tahun, 10-12 tahun, 13-15 tahun dan 16-9 tahun.

Pada penelitian ini usia sampel berusia 13-15 tahun dimana terdapat item tes khusus usia tersebut yang pada intinya sama bertujuan untuk mengetahui hasil kebuagaran jasmani. tes kebugaran jasmani merupakan alat ukur yang bertujuan untuk mengetahui kebugaran anak usia 13 tahun-19 tahun item tes terdiri dari putra : Iari 50 meter,gantung angkat tubuh selama 60 detik, baring duduk selama 60 detik, loncat tegak, lari jauh 1000 meter dan item untuk putri : lari 50 meter, gantung siku tekuk 60 detik, baring duduk 60 detik, loncat tegak, lari jauh 800 meter (Widiastuti, 2017; Budi, 2015) 
Dani Wardani \& Alwi Nurudin | Pengaruh Senam Bugar Muhammadiyah Terhadap Kebugaran Jasmani Siswa SMP

HASIL

Setelah dilakukan tes awal dan tes akhir kemudian dilakukan pengolahan data yang terdapat hasil tes awal sebelum diberikan perlakuan dan tes akhir setelah diberikan perlakuan.

Tabel 1. Analisis Hasil Data tes awal dan Tes akhir Kebugaran Jasmani

\begin{tabular}{lccccc}
\hline \multicolumn{1}{c}{ Tes Kebuaran Jasmani Indonesia } & N & Jumlah & Rata-rata & SD & Var \\
\hline Tes Awal Kebugaran & 4 & 36 & 9 & 2.30 & 4 \\
\hline Tes Akhir Kebugaran & & 43 & 10.75 & 2.87 & 6.18 \\
\hline
\end{tabular}

Berdasarkan penjelasan tabel 1 setelah dilakukanya tes awal menggunakan tes kebugaran jasmani Indonesia dapat diketahui bahwa nilai dari tes awal kebugaran jasmani $\mathrm{N} 4$, untuk jumlah keseluruhan dari setiap item tes waktu tes awal 36 detik dengan nilai rata-rata 9 dan SD 2,30. Kemudian jumlah keseluruhan dari setiap item tes waktu tes akhir 43 detik dengan nili rata-rata 10,75 dan SD 2,87.

Uji normalitas menggunakan Microsoft. Exel 2010 pengujian uji normalitas dapat dilakukan setelah mengolah data tes awal dan akhir serta telah diketahui hasil nilai ratarata dan SD. Setelah diketahui kemudian melakukan uji normalitas dengan metode pendekatan uji kenormalan Lilyfors.

Tabel 2. Hasil Uji normalitas tes awal dan tes akhir kebugaran jasmani

\begin{tabular}{llccccc}
\hline \multicolumn{1}{c}{ Tes } & $\mathbf{N}$ & Mean & SD & Lhitung & Ltabel & Ket \\
\hline Awal & 4 & 9 & 2.30 & 0.30 & 0.83 & Normal \\
\hline Akhir & 4 & 10.75 & 2.87 & 0.34 & 0.83 & Normal \\
\hline
\end{tabular}

Hasil dari uji normalitas pada tes awal diperoleh Lhitung $=0,30$ lebih kecil dari taraf nyata penolakan $\alpha: 0,05$ yaitu Ltabel $=0,83$. Dapat disimpukan bahwa data tes ini termasuk distribusi normal. Hasilnya normal karena $L$ hitung $0,30<$ dari Ltabel 0,83 artinya distribusi normal atau sesuai dengan kaidan statistika. Kemudian hasil uji nomalias pada tes akhir diperoleh Lhitung $=0,30$ lebih kecil dari taraf penolakan $\alpha: 0,05$ yaitu Ltabel $=0,83$. Dapat disimpukan bahwa data tes ini termasuk distribusi normal. Hasilnya normal karena $L$ hitung $0,34<$ dari Ltabel 0,83 artinya distribusi normal.

Uji homogenitas dapat dilakukan setelah mengetahui hasil dari varians tes awal dan akhir yang dapat dihitung dengan cara sebagai berikut: 
Tabel 3. Tabel Penghitungan Homogenitas tes awal dan akhir

\begin{tabular}{ccc}
\hline Fhitung & Ftabel & Kesimpulan \\
\hline 1.54 & 9.27 & Homogeny \\
\hline
\end{tabular}

Dari hasil uji homogenitas yang bertujuan untuk mengetahui apakah populasi itu sama atau tidak. Dari tabel diatas dapat diketahui hasilnya Fhitung = 1,54 lebih besar dari Ftabel $=9,27$. Dapat disimpukan $\mathrm{HI}$ ditolak yang artinya bahwa data dari penelitian ini homogen atau sama. Hal ini jelas bahwa data data penelitian ini homogen yang artinya sama dan dapat dilanjutkan menghitung uji t hipotesis.

Tabel 4. Pengujian nilai dari hasil Latihan senam bugar muhammadiyah

\begin{tabular}{ccc}
\hline Thitung & Ttabel & Keterangan \\
\hline 0.949 & 2.44 & Tidak Signifikan \\
\hline
\end{tabular}

Hasil dari penghitungan yang menggunakan metode pendekatan uji t hasil yang diperoleh 0,949. Hasil tersebut lebih kecil dari Tatabel yang berjumlah 2,44, oleh karena itu hipotesis Ha ditolak, yang artinya $\mathrm{Ho}=$ tidak ada pengaruh yang signifikan dari latihan senam bugar muhammadiyah terhadap kebugaran jasmani siswa kelas VIII. H SMP Negeri Kadudampit Kabupaten Sukabumi.

\section{PEMBAHASAN}

Senam umum adalah kegiatan olahraga yang memiliki beberapa jenis senam yang mudah diikuti dan geraknya dirangkai dengan tempo menyesuaikan musik dan hitungan. Mury \& Rachmanida (2015) dan Rubiana (2020) menjelaskan bahwa senam umum adalah bagian dari pada senam yang mana pelaksanaan aktivitasnya menggunakan musik yang termasuk kedalam senam umum adalah senam aerobic, SKJ, poco-poco, maumere, dan Zumba. Helvi (2018) dan Setiawan et al. (2020) senam adalah aktivitas fisik yang dilakukan sebagai cabang olahraga tersendiri maupun sebagai latihan untuk cabang olahraga lainya. Berlainan dengan cabang olahraga lain pada umumnya yang mengukur aktifitas pada objek tertentu, senam mengacu pada bentuk gerak yang dikerjakan dengan kombinasi terpadu dan menjelma dari setiap bagian anggota tubuh dari komponenkomponen kemampuan motorik seperi: kekuatan, kecepatan, keseimbangan, kelincahan 
Dani Wardani \& Alwi Nurudin | Pengaruh Senam Bugar Muhammadiyah Terhadap Kebugaran Jasmani Siswa SMP

dan ketepatan. Dapat ditarik kesimpulan bahawa senam merupakan cabang olahraga yang merangkai gerkan dengan mengikuti musi tertentu dan dapat dilakukan sebagai metode latihan untuk mengukur aktifitas objek sesuai dengan komponen yang dipilih.

Latihan adalah proses melakukan kegiatan yang telah terkonsep dan memiliki tujuan yang jelas sehingga akan terciptanya tujuan yang diharapkan. Zena \& Supriadi (2016) menjelaskan bahwa latihan adalah proses melakukan kegiatan olahraga yang telah direncanakan secara sistematis dan tersetuktur dalam jangka waktu yang lama untuk meningkatkan kemampuan gerak baik dari segi fisik, tehnik, taktik, untuk menunjang keberhasilan siswa atau atlit. Lebih lanjut Satriya et al. (2013) menjelaskan volume latihan ialah jumlah atau kuantitas materi yang harus dilakukan dalam satu unit latihan. Volume Latihan bisa berupa: lamanya latihan (menit, jam), berat beban yang harus diangkat $(\mathrm{kg})$, jauhnya jarak yang harus dilakukan (10 kali, 50 kali, 100 kali). Menurut (Ahmad, 2014) Prinsip Latihan yang perlu diketahui harus didasari prinsip beban berlebih (over load) artinya, manakala tiba saatnya untuk ditingkatkan, namun masih dalam tahap batas-batas kemampuanya.

Hasil dari penelitian ini bahwa tidak ada pengaruh yang signifikan dari senam bugar muhammadiyah karena sampel tidak menguasai gerakan senam sehingga berpengaruh terhadap hasil yang tidak sesuai dengan harapan kebugaran jasmani siswa kelas VIII. H SMP Negeri 1 Kadudampit Kabupaten Sukabumi tahun ajaran 2020/2021. Oleh karena itu perencanaan program latihan hal yang paling penting berguna untuk memperkirakan adanya pengaruh dari triment yang diberikan terhadap kebugaran jasmani.

Keterbatasan paa penelitian ini yaitu adanya wabah penyakit covid 19. Oleh karena itu peneliti mengurangi jumlah sampel yang awalnya 23 sampel menjadi 4 sampel . Mengenai pengurangan sampel yang pertama sesuai dengan kaidah norma tes kebugaran jasmani yang hanya bisa mengikuti triment senam bugar muhammadiyah ini berusia 13-15 tahun dan yang kedua karena adanya wabah penyakit yang disesuaikan dengan tehnik pengambilan data dan pertimbangan-pertimbangan demi keselematan.

\section{SIMPULAN}

Berdasarkan hasil analisis data dan pembahsan, dapat kesimpulan bahwa tidak ada pengaruh latihan senam bugar muhammadiyah terhadap kebugaran jasmani siswa 
kelas VIII. H SMP Negeri 1 Kadudampit Kabupaten Sukabumi dikarenakan kurang menguasai gerakan senam bugar muhammadiyah pada saat proses latihan, sehingga mempengaruhi hasil kebugaran jasmani. Saran dari peneltian ini yaitu senam bugar Muhamadiyah perlu dikaji lebih jauh dengan menggunakan jumlah sampel yang lebih banyak dan dengan metode latihan yang lebih terprogra, sehingga dapat diketahui pengaruh yang lebih nyata.

\section{REFERENSI}

Ahmad, J. (2014). Dini Melalui Pusat Pembinaan Dan Latihan Pelajar ( Pplp ) Dan Pusat Pembinaan Dan Latihan Mahasiswa. Jurnal Pendidikan Olah Raga, 3(2), 156-168.

Budi, D. R. (2015). Pengaruh Modifikasi Permainan Vobas dan Kebugaran Jasmani terhadap Peningkatan Kerjasama Siswa dalam Pembelajaran Penjas di SMP. Thesis. Retrieved from http://repository.upi.edu/id/eprint/17605

Edo, P. (2017). Tingkat Kebugaran Jasmani Berdasarkan Indeks Massa Tubuh Pada Siswa Megeri 29 Bengkulu Utara. Jurnal IImiah Pendidikan Jasmani, 1(2), 86-91.

Helvi, D. (2018). Pengaruh Senam Aerobik Low Impact Terhadap Peningkatan Vo2max. Jurnal Gelanggang Ollahraga, 1(2), 42-51.

Juliasti, E., Kuswari, M., \& Jus'at, I. (2020). Senam Irama Lagu Gizi Seimbang Meningkatkan Kebugaran Pada Anak Sekolah. Journal Sport Area. https://doi.org/10.25299/sportarea.2020.vol5(1).4053

Kusnandar, K., Purnamasari, D. U., Nurcahyo, P. J., \& Darjito, E. (2019). Pengaruh Permainan Tradisional Banyumas Gol-Golan Terhadap Tingkat Kebugaran Jasmani Siswa Sekolah Dasar Di Kabupaten Banyumas. Physical Activity Journal. https://doi.org/10.20884/1.paju.2019.1.1.1996

Mury, K., \& Rachmanida, N. (2015). Pengaruh Senam Aerobik Intensitas Sedang ( Low. Nutrire Diaita.

Rahmat, P. (2016). ( TKJI ) Melalui Diskusi Dan Simulasi. Jurnal Reflika Edukatika, 6(2), $119-129$

Rubiana, I. (2020). Memasyarakatkan Olahraga Dan Mengolahragakan Masyarakat Melalui Senam Umum. Abdimas Siliwangi, 03(01), 130-137.

Satriya, Dikdik, \& Imanudin. (2013). Teori Latihan Olahraga (2014th ed.; R. U. Setria, ed.). Bandung.

Setiawan, A., Yudiana, Y., Ugelta, S., Oktriani, S., Budi, D. R., \& Listiandi, A. D. (2020). Hasil Belajar Pendidikan Jasmani dan Olahraga Siswa Sekolah Dasar: Pengaruh 
Keterampilan Motorik (Tinggi) dan Model Pembelajaran (Kooperatif). TEGAR: Journal of Teaching Physical Education in Elementary School. https://doi.org/10.17509/tegar.v3i2.24513

Sugiyono. (2012). Metode Penelitian Kuantitatif Kualitatif dan R\&D (17th ed.). Bandung: 2012.

Suhartoyo, T., Budi, D. R., Kusuma, M. N. H., Syafei, M., Listiandi, A. D., \& Hidayat, R. (2019). Identifikasi Kebugaran Jasmani Siswa SMP Di Daerah Dataran Tinggi Kabupaten Banyumas. Physical Activity Journal. https://doi.org/10.20884/1.paju.2019.1.1.1995

Wening. (2018). Prosiding Konferensi Nasional ke -8 UMSU (2019th ed.; Y. Nurul, ed.). Yogyakarta: 2019.

Widiastuti. (2017). Tes Dan Pengukuran Olahraga (2nd ed.). Jakarta.

Zena, L. A., \& Supriadi. (2016). Pengaruh Model Latihan Menggunakan Metode Praktik Distribusi Terhadap Keterampilan Dribble Anggota Ekstrakurikuler Bolabasket SMPN 18 Malang. Jurnal Kepelatihan Olahraga, 1(1), 1-15. 